\title{
Growth and yield of anthurium in response to sawdust mulching
}

\author{
Crescimento e produção de antúrio em resposta a \\ cobertura do solo com serragem de madeira
}

\author{
Juliana Domingues Lima ${ }^{\mathrm{I}^{*}}$ Samara Zanetti $^{\mathrm{I}}$ Edson Shigueaki Nomura ${ }^{\mathrm{II}}$ \\ Eduardo Jun Fuzitani ${ }^{\mathrm{II}}$ Danilo Eduardo Rozane ${ }^{\mathrm{I}}$ Piero Iori $^{\mathrm{I}}$
}

\section{ABSTRACT}

The objectives of the study were to analyze the effect of sawdust mulch on the: (1) soil characteristics; (2) growth and flower yield of the anthurium cv. 'Apalai'. Assay was conducted in a totally randomized design in subdivided plots, with five treatments and eight replications. The treatment consisted of five volumes of sawdust 0 , 20, 40, 60 and $80 \mathrm{~L} \mathrm{~m}^{-2}$, distributed over the bed, every three months. Soil, plants and flower stalks were evaluated during two years. Soil temperature, moisture, organic matter, bulk density and water retention conditions were improved, while the leaf area of plants and the yield of flower stalks were increased when the soil were mulched with sawdust. In addition to increasing soil organic matter, however, no change occurred in the level of nutrients in plants. Sawdust also improved the dimension of flower stalks. Application of $40 \mathrm{~L} \mathrm{~m}^{-2}$ of sawdust every three months is recommended.

Key words: floriculture, Anthurium andraeanum, soil cover, wood residue, flowering interval.

RESUMO

Objetivou-se analisar o efeito da serragem de madeira: (1) nas características do solo; (2) no crescimento e produção de hastes florais de anthurium cv. 'Apalai'. O ensaio foi conduzido em delineamento inteiramente casualizado em parcelas subdivididas, com cinco tratamentos e oito repetições. Os tratamentos consistiram em cinco volumes de serragem 0, 20, 40,60 e $80 \mathrm{~L} \mathrm{~m}^{-2}$, distribuídos sobre os canteiros, a cada três meses. $O$ solo, as plantas e hastes florais foram avaliados por dois anos. A temperatura, a umidade, o teor de matéria orgânica, a densidade e a retenção de água do solo melhoraram, enquanto a área foliar e a produção de hastes florais aumentaram quando o solo foi coberto com serragem. Apesar do aumento do teor de matéria orgânica, não ocorreram modificações no teor de nutrientes nas plantas. A serragem também melhorou as dimensões das hastes florais. Recomenda-se aplicação de $40 \mathrm{~L} \mathrm{~m}^{-2}$ de serragem a cada três meses.
Palavras-chave: floricultura, Anthurium andraeanum, cobertura do solo, resíduo florestal, intervalo de floração.

\section{INTRODUCTION}

Anthurium, for its exquisiteness, durability, and long vase-life stands out among most cultivated tropical flowers (GANTAIT \& MANDAL, 2010). This flower belongs to the largest genus of Araceae family that encompasses over 1500 species, of which 600 species are from Tropical America (VENKAT et al., 2014). Anthurium andreanum Linden ex André (anthurium) is the most known, which plays a significant role in the global floriculture trade. Is a slow-growing perennial which requires warm, shady, humid conditions, as well as soil with good water retention capacity and good drainage (COLLETTE et al., 2004).

In soil management, appropriate mulching provides environmental and agronomical advantages such as preventing weed growth (SINKEVIČIENÉ et al., 2009), controlling diurnal/seasonal fluctuations in soil temperature, protecting soil from erosion (JAFARI et al., 2012) or increasing water use efficiency by reducing evaporation (JUN et al., 2014). Organic mulching and its skillful application can lead to improved

\footnotetext{
'Universidade Estadual Paulista "Júlio de Mesquita Filho" (UNESP), Campus Experimental de Registro, Rua Nélson Brihi Badur, 430, Vila Tupy, 11900-000, Registro, SP, Brasil. E-mail: judlima@registro.unesp.br. "Corresponding author.

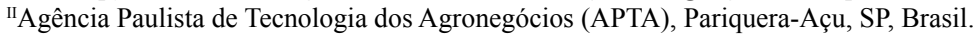


soil organic matter contents (YOUNIS et al., 2012), recovering other soil characteristics as aggregation, water holding capacity (MUPANGWA et al., 2013), and nutrients content (JUN et al., 2014). As consequence, in general, increase the economic productivity of horticultural crops.

The usefulness of different mulching materials to different floriculture crops is well accepted (YOUNIS et al., 2012). Organic matter also can serve as good medium to anchor adventitious roots for anthurium (HIGAKI et al., 1995). However, limited research had been done with use of mulches. The objectives of the study were to analyze the effect of sawdust mulch on the: (1) soil characteristics; (2) growth and flower yield of the anthurium cv. 'Apalai'.

\section{MATERIALS AND METHODS}

The experiment was conducted on a flower farm in the municipality of Pariquera-Açu SP, Brazil, $24^{\circ} 36^{\prime} 31^{\prime \prime} \mathrm{S}$ and $47^{\circ} 53^{\prime} 48^{\prime \prime} \mathrm{W}$, at $25 \mathrm{~m}$ above MSL. According to Köppen, the region's climate is tropical humid without a well-defined dry season (Af). The accumulated rainfall during the experimental was $1573 \mathrm{~mm} \mathrm{year}^{-1}$ and the average minimum and maximum temperatures were $25.9^{\circ} \mathrm{C}$ and $16.7^{\circ} \mathrm{C}$, respectively. The soil of the area was Oxisols, typic Hapludox (SOIL SURVEY STAFF, 2010), with $39 \%$ of clay, $16 \%$ of silt and $45 \%$ of sand.

Plant material was Anthurium andraeanum cv. 'Apalai' (IAC NK 130), which is vigorous and productive with rounded spathe, red and white spadix with yellow apex, widely cultivated and marketed in São Paulo with good acceptance. The micropropagated seedlings were transplanted for beds measuring $1.20 \mathrm{~m}$, spaced at $0.40 \times 0.40 \mathrm{~m}$ intervals in width, laid out in the nursery area covered at a height of three meters with a black netting to provide $70 \%$ shade. The experiment was installed out with plants adult, about 22 months after transplantation, in a totally randomized design, subdivided into plots, with five treatments and eight replications. The treatment consisted of five volumes of sawdust $0,20,40,60$ and $80 \mathrm{~L} \mathrm{~m}^{-2}$ distributed over the bed every three months. Sawdust was first applied in July 2011, or rather, at the start of the harvest of marketable flower stalks, twelve months after transplanting. The final sawdust application occurred in April 2013. Analysis of mulching material had the following average characteristics: $\mathrm{N}$ : $0.26 \%$; $\mathrm{P}$ :
0.03\%; Ca: 0.27\%; Mg: 0.05\%; Na: $150 \mathrm{mg} \mathrm{kg}^{-1}$; Cu: $6 \mathrm{mg} \mathrm{kg}^{-1}$; Fe: $135 \mathrm{mg} \mathrm{kg}^{-1}$; Mn: $24 \mathrm{mg} \mathrm{kg}^{-1} ; \mathrm{Zn}: 4 \mathrm{mg}$ $\mathrm{kg}^{-1}$; $\mathrm{pH}$ : 5.10; moisture: $53 \%$; total C 25\%; C/N ratio $96 / 1$. Fertilization was maintained with $20 \mathrm{~g}$ of NPK per plant, at 10-10-10, every two months. The lateral buds were eliminated and only one plant per clump was maintained. Plants did not receive any irrigation or leaf trimming.

Upon application of sawdust, the leaves were counted and their dimensions taken. Total leaf area was estimated by equation established by MODENESE-GORLA DA SILVA et al. (2008). Inflorescence commercial harvest point ( $1 / 2$ to $3 / 4$ of open flowers on the spadix) were evaluated every week. Further, inflorescence was harvested to determine its dimension (size of flower stalk, width and length of spathe and length of spadix).

The temperature of soil was determined every 15 days at a depth of $15 \mathrm{~cm}$. Fortnightly also, soil samples were collected to quantify water content by the gravimetric method (EMBRAPA, 1997). Undisturbed soil samples of a $5.1 \mathrm{~cm}$ length and a $5 \mathrm{~cm}$ diameter were collected on days 210,570 and 720 after sawdust implementation to determine the capacity of water retention at different tensions (FREITAS JUNIOR \& SILVA, 1984). Moisture and water potential values observed were adjusted by the equation of Van GENUCHTEN (1980), through the SWRC software version 2.0 (DOURADONETO et al., 2000).

Sampling and measures were always performed in triplicate. Temperature and precipitation data were collected daily from the weather station. Experimental data were subjected to analysis of variance ( $F$ test) and differences between treatment means were compared by Tukey's test. Regression analysis determined the most appropriate volume of sawdust and correlation between variables was determined by Pearson's coefficient.

\section{RESULTS AND DISCUSSION}

Average minimum and maximum temperatures during the experimental period were 16.8 and $26.3^{\circ} \mathrm{C}$ respectively. Absolute temperatures ranged between 5.0 and $39.2^{\circ} \mathrm{C}$, exceeding on some days the maximum daytime limit of $35^{\circ} \mathrm{C}$ and nigh time minimum threshold of $18^{\circ} \mathrm{C}$ (DUFOUR \& GUÉRIN, 2003). Total accumulated rainfall was $3080.2 \mathrm{~mm}$.

Temperature monitoring of soil revealed a linear behaviour of the variable which depended 
on the volume of sawdust (Figure 1A), displaying an average minimum temperature of $20.61^{\circ} \mathrm{C}$ in the absence of coverage and maximum of $22.85^{\circ} \mathrm{C}$ when $80 \mathrm{~L} \mathrm{~m}^{-2}$ of sawdust were applied. The above data demonstrates that soil cover elevated soil temperature by $2.24^{\circ} \mathrm{C}$, perhaps due to the decomposition of material used and to the heat generated by the metabolism of microorganisms.
Soil temperature also varied as a function of time after the application of the sawdust (Figure 1B). This reflected the effect of the physical protection of the soil but also the climatic conditions to which the crop canopy and soil were submitted. Similar behaviour was reported (Figure 1B) when air temperature, soil without cover and protected by sawdust were related to the time. Air temperature

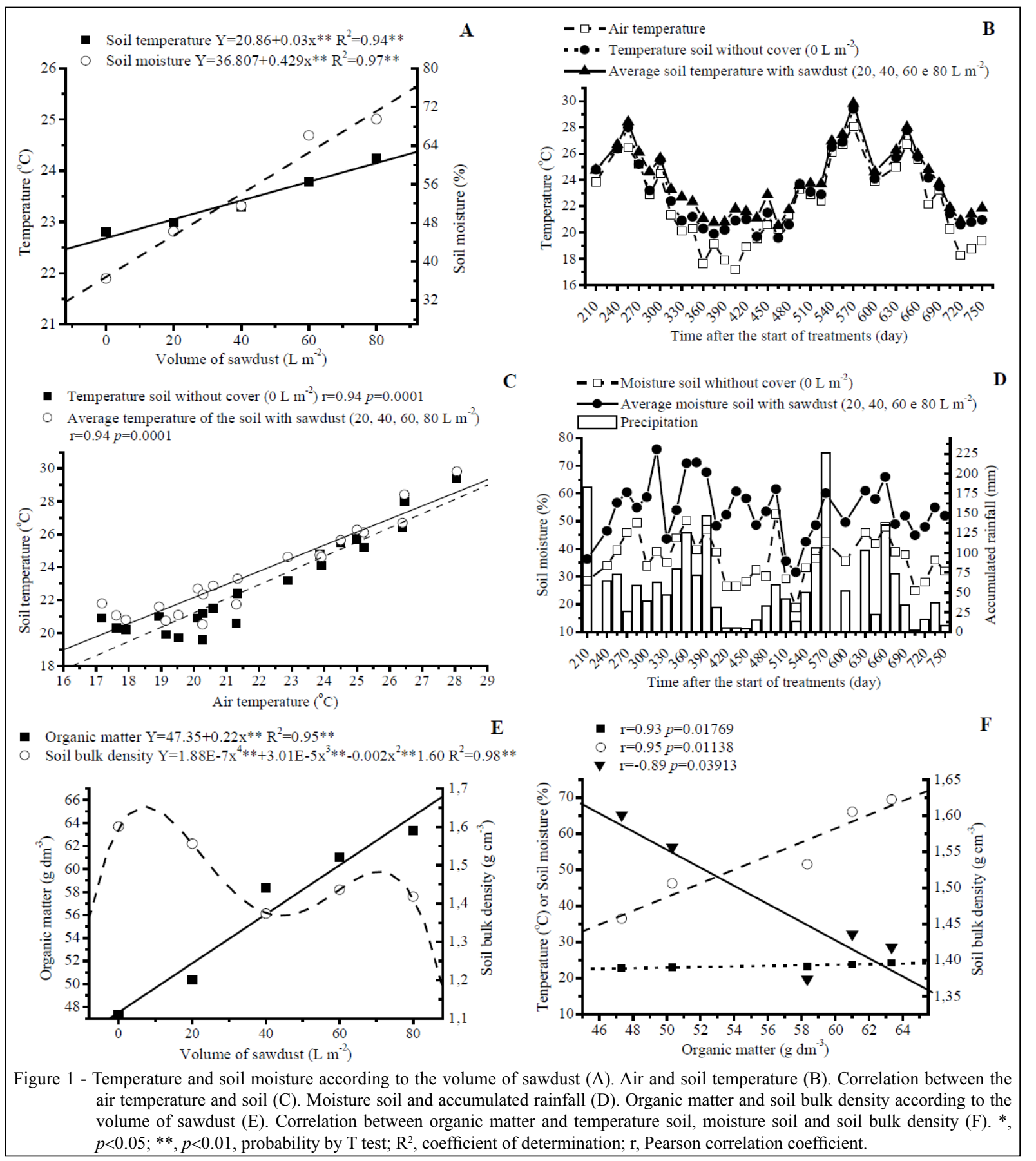

Ciência Rural, v.46, n.3, mar, 2016. 
tended to be lower than that of the soil during the colder months regardless of the presence of cover. Positive correlation between soil temperature, with or without cover, and the air temperature was observed (Figure 1C) and between organic matter content and temperature (Figure 1D). Increased soil temperature observed in the mulched plots also agreed with the findings of RAMAKRISHNA et al. (2006). Under straw mulch, ZHANG et al. (2009) and JUN et al. (2014) also observed that soil temperature decreased in the warmer period and increased in the colder period when compared to those of non-mulched soil.

Soil moisture showed a linear behaviour according to the volume of sawdust applied (Figure $1 \mathrm{~A})$, with initial and final rates respectively at $37 \%$ and $71 \%$ confirming that the sawdust contributed towards high moisture rates. Soil moisture of the bed as a function of time after the start of treatment did not show a characteristic behaviour to be described by a regression model. When comparing soil moisture in absence and presence of sawdust, the moisture of soil covered was always higher than in the absence of sawdust. Straw mulch and gravel mulch both enhanced soil water content at the $15 \mathrm{~cm}$ depth (JUN et al., 2014).

Considering the whole experimental period, it was also not possible to establish a correlation between accumulated rainfall and soil moisture (Figure 1D). However, in the period with low cumulative rainfall (400-460 days), the soil moisture without cover decreased linearly with decreasing precipitation, response that did not occur in the soil with cover (Figure 1D), probably due to reduction in water evaporation from the surface and to an increase in the amount of infiltrated water. Soil profile moisture content, water infiltration rate and hydraulic conductivity in soil with mulching were significantly higher, than without cover (KUOTSU et al., 2014). Retention of residues on the soil surface also reduced water evaporation (ZHANG et al., 2009; KUOTSU et al., 2014).

The sawdust mulching changed the shape of the soil water retention curve at 210 days after the implementation (Figure 2A). The treatment without sawdust registered the lowest water contents at several tensions at 210 and 570 days, while the application of sawdust provided greater retention of water (Figure 2B). After 570 days, the application of $40 \mathrm{~L} \mathrm{~m}^{-2}$ had the highest water contents in all applied tensions. At 720 days (Figure 2C) the highest water retention occurred

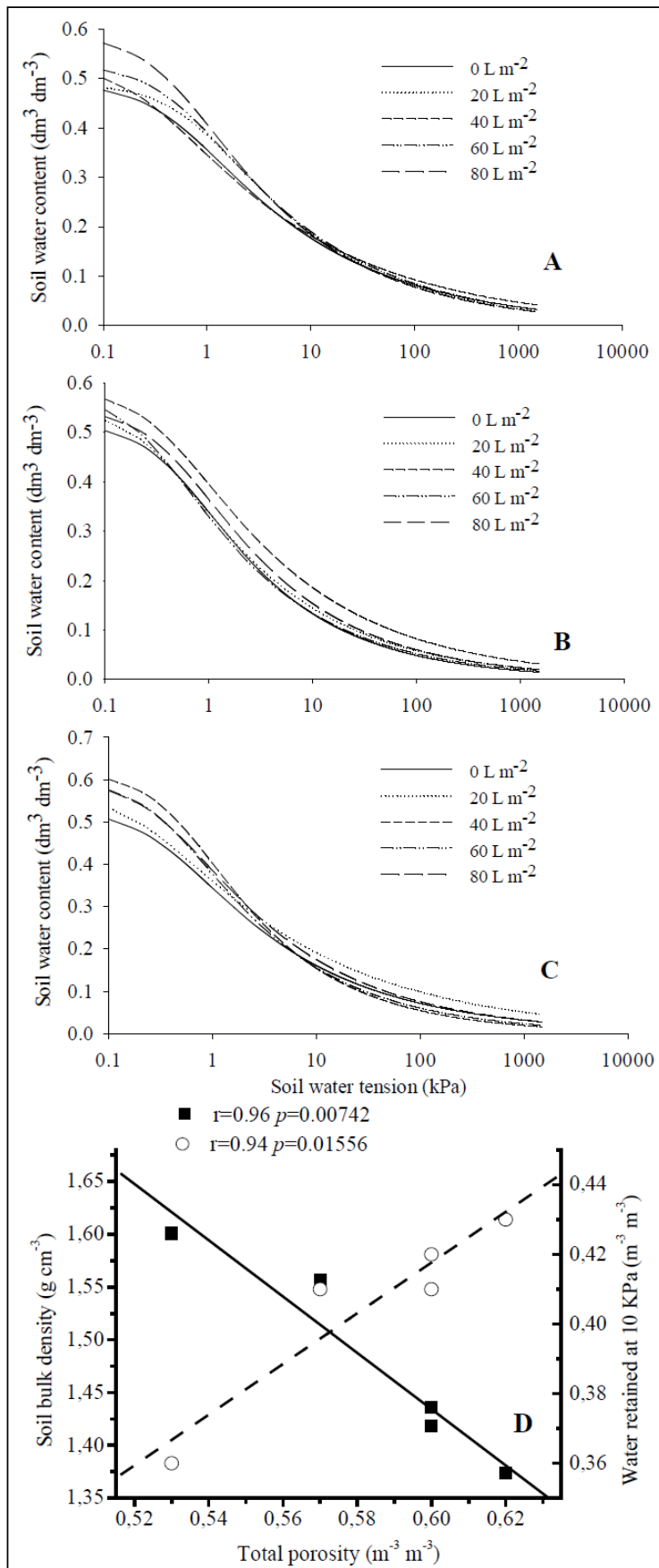

Figure 2 - Water retention curves at 210 (A) 570 (B) and 720 (C) days after the distribution of sawdust on the soil surface. Correlation between soil bulk density, total porosity and water content retained at $10 \mathrm{KPa}$ (D). r, Pearson correlation coefficient, $p$, probability by $\mathrm{T}$ test.

in the soil at tensions below $10 \mathrm{kPa}$ in soil that received $40 \mathrm{~L} \mathrm{~m}^{-2}$. However, at higher tensions the soil with $20 \mathrm{~L} \mathrm{~m}^{-2}$ of sawdust retained more water. Although based on water retention curves, it was not possible to establish the best volume of

Ciência Rural, v.46, n.3, mar, 2016. 
sawdust, even though there was no doubt on the benefits of cultural practice. In fact, it provided improvements in the physical conditions and the rise of the soil's organic matter levels in proportion to the amount invested (Figure 1E). Higher average rates of soil moisture in plots with cover (Figure 1D) corroborate with water retention curves obtained (Figure 2). Such a response can also be supported by significant correlations between organic matter and soil moisture (Figure 1F), bulk density and porosity or retained water content (Figure 2D). In other words, treatments with sawdust showed higher average rates of soil moisture due to greater water retention. Regardless of the volume, soil with sawdust showed a soil bulk density decrease (Figure 1E), with mean value of $1.45 \pm 0.10 \mathrm{~g} \mathrm{~cm}^{-3}$, whereas the soil without sawdust averaged $1.60 \pm 0.08 \mathrm{~g}$ $\mathrm{cm}^{-3}$. Mulching reduced soil bulk density through promotion of aggregation and pore development in the soil system as the residues decomposed (MULUMBA \& LAL, 2008; MUPANGWA et al., 2013). There was also a reduction of bulk density due to the volume of sawdust. MULUMBA \& LAL (2008) also established no linear relationship between mulch rate and soil bulk density. There was a linear correlation between organic matter content and soil characteristics, temperature, moisture and density (Figure 1G).

Despite the increase in level organic matter in soil, no changes in nutrient content of leaf due to applied sawdust volume occurred. Regardless of treatments, the average content of macronutrients in the leaves to $\mathrm{N}, 25.1, \mathrm{P}$, $2.78, \mathrm{~K}, 41.1, \mathrm{Ca}, 18.8, \mathrm{Mg}, 6.89 \mathrm{~g} \mathrm{~kg}^{-1}$ and micronutrients, $\mathrm{B}, 65.2, \mathrm{Cu}, 13.5, \mathrm{Fe}, 160.4, \mathrm{Mn}$, 437.9, Zn, 79.1 $\mathrm{mg} \mathrm{kg}^{-1}$. N, K, Ca, S, B, Fe, Mg and $\mathrm{Cu}$ contents were at an adequate level in the leaves, with Mn very much higher than required (TOMBOLATO et al., 2002). Nevertheless, there were no phytotoxicity symptoms.

Since the plants total leaf area increased as a function of time, the soil-climate conditions were favourable to growth. Increase in leaf area owing to anthurium development complies with the fact that plant in juvenile stage has smaller leaves and larger ones in the adult stage (DUFOUR \& GUÉRIN, 2003). In fact, a linear response in the growth for plants of all treatments was obtained when the total leaf area was correlated with the volume of sawdust (Figure 3A). The number of flower stalks, flowering interval, flower stalk length and spathe length were also affected by the volume of sawdust applied and contrastingly to the leaf area, there was a quadratic growth response to soil cover (Figure 3B and 3C). Average flower stalks produced in soil with and without sawdust were respectively 5.44 and 6.56 years $^{-1}$, very close to averages reported by NOMURA et al. (2011). However, despite very similar production, soil protection promoted plant growth when mean rates of the size of the flower stalk were compared (Figure 3C). In fact, it contributed towards an increase in the quality. When quality is taken into account, soil cover induced longer flower stalks and only flower stalks harvested from plants grown with $80 \mathrm{~L} \mathrm{~m}^{-2}$ of sawdust reached the average minimum length of $60 \mathrm{~cm}$. This is an important feature for classification, although Brazilian domestic consumer market accepts shorter flower stalks (TOMBOLATO et al., 2002).

Soil cover also reduced flower mortality during the experimental period, or rather, a $2 \%$ average in plants cultivated with sawdust-covered bed when compared to a $10 \%$ average in plants growing without any sawdust cover. No difference occurred between treatments with regard to defective inflorescences harvested (deformity) and spathe defects (blemish, deformity, disease or pest attack) which together constituted $5 \%$ of harvested flowers. Spathes with a regular red colour were observed in plants from different treatments.

Increase of flower stalks, decrease in flowering interval, length increase of flower stalk and spathe confirmed that sawdust over $40 \mathrm{~L} \mathrm{~m}^{-2}$ provided the most appropriate condition for cultivation. There was a linear correlation between organic matter content of soil and the growth characteristics of the plant, total leaf area (Figure 3D), production as number of flower stalks plant ${ }^{-1}$ and flowering interval and quality, as flower stalk length (Figure 3E) and spathe length (Figure 3F). Other studies reported that the quality of ornamental plants and the yield can be improved through application of mulch (BLAZEWICZ-WOZNIAK et al., 2011; YOUNIS et al., 2012; LASKOWSKA et al., 2012).

\section{CONCLUSION}

The sawdust mulching is an asset to anthurium cultivation by improving the soil's organic matter content, stimulating plants growth and yield when compared results with bare soil. The application of $40 \mathrm{~L} \mathrm{~m}^{-2}$ of sawdust every three months is recommended. 


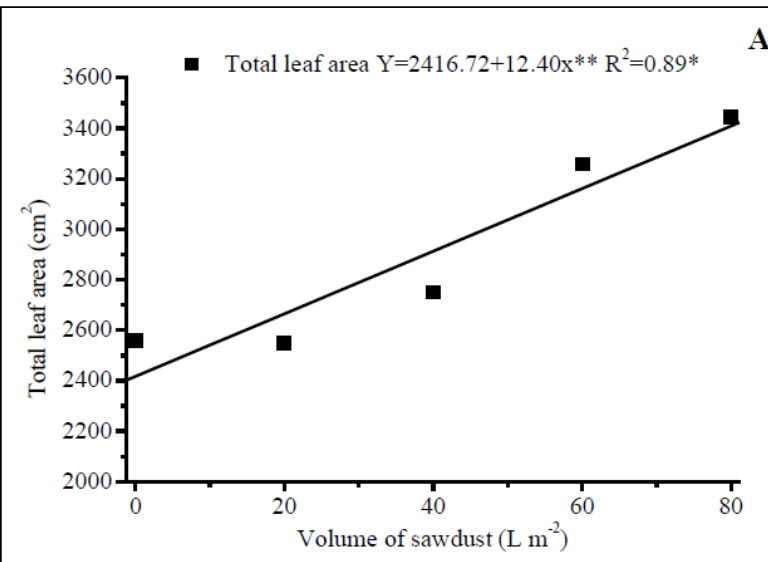

- Number of flower stalks $\mathrm{Y}=10.74+0.08 \mathrm{x} * *-6.70 \mathrm{E}-4 \mathrm{x}^{2} * * \mathrm{R}^{2}=0.87 * *$ B Flowering interval $\mathrm{Y}=67.29-0.34 \mathrm{x}^{* * *}+0.003 \mathrm{x}^{2}{ }^{2 * *} \mathrm{R}^{2}=0.99^{* *}$

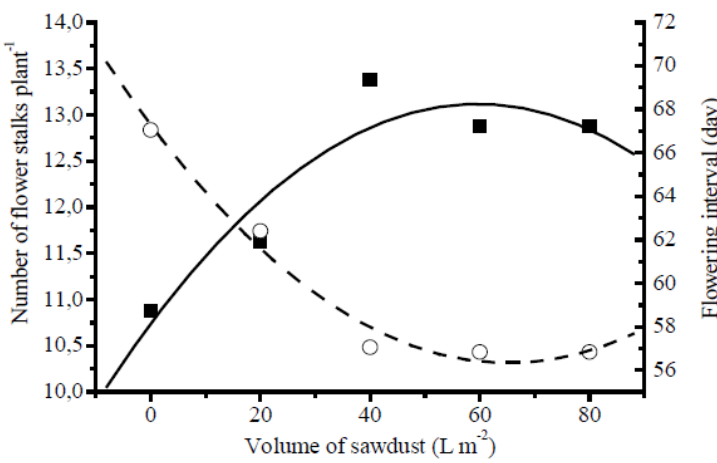

Flower stalk length $\mathrm{Y}=47.71+0.28 \mathrm{x} *-0.002 \mathrm{x}^{2} * * \mathrm{R}^{2}=0.89 * * \quad \mathrm{C}$ Spathe length $\mathrm{Y}=10.27+0.03 \mathrm{x} *-2.41 \mathrm{E}-4 \mathrm{x} *-7.29 \mathrm{E}-5 \mathrm{x} * \mathrm{R}^{2}=0.91 * *$

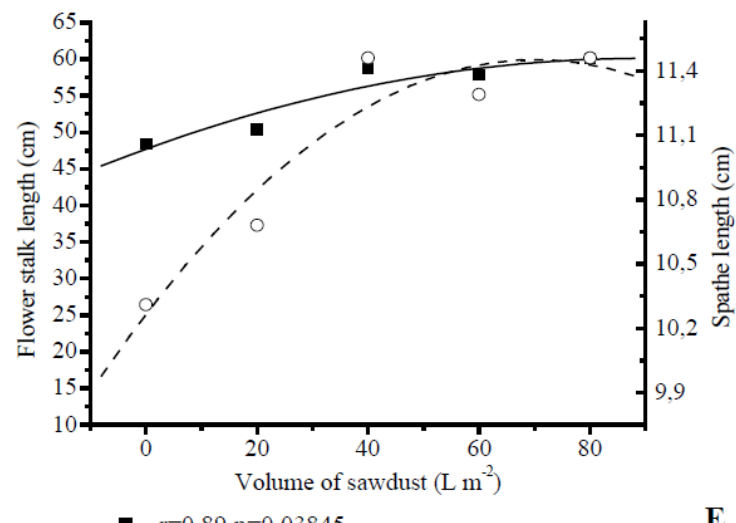

- $\mathrm{r}=0.91 p=0.03453$

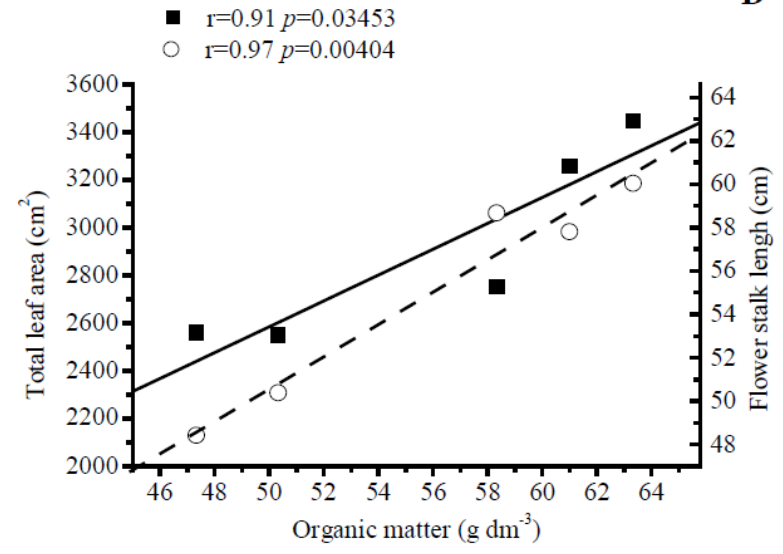

- $\mathrm{r}=0.89 \mathrm{p}=0.03845$

$\mathbf{E}$

$\mathrm{r}=-0.95 p=0.01321$
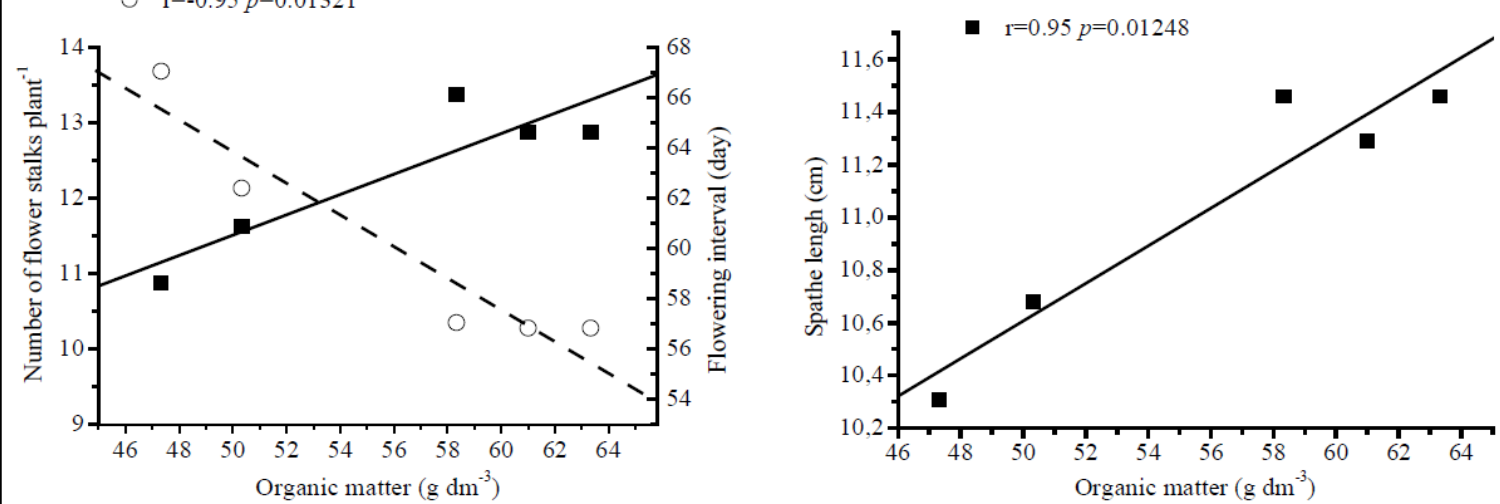

Figure 3 - Total leaf area (A), number of flower stalks and flowering interval (B), flower stalk and spathe length (C) according with the volume of sawdust. Correlation between content of soil organic matter and total leaf area, flower stalk length (D), number of flower stalks, flowering interval (E) and spathe length (F). ${ }^{*}, p<0.05 ;{ }^{*}, p<0.01$, probability by $\mathrm{T}$ test; $\mathrm{R}^{2}$, coefficient of determination; r, Pearson correlation coefficient.

\section{ACKNOWLEDGMENTS}

To Fundação de Amparo à Pesquisa do Estado de São Paulo (FAPESP) for the research grant given to the second author (2011/20193-2).

\section{REFERENCES}

BLAZEWICZ-WOZNIAK, M. et al. Flowering of bear garlic (Allium ursinum L.) cultivated in the field at varied nitrogen nutrition and mulching. Acta Scientiarum Polonorum, v.10, n.3, 
p.133-144, 2011. Available from: <http://www.cabi.org/cabdirect/ FullTextPDF/2011/20113290071.pdf>. Accessed: Mar. 31, 2015.

COLLETTE, V.E. et al. Temporal and spatial expression of flavonoid biosynthetic genes in flowers of Anthurium andraeanum. Physiologia Plantarum, v.122, n.3, p.297304, 2004. Available from: <http://onlinelibrary.wiley.com/ doi/10.1111/j.1399-3054.2004.00402.x/full>. Accessed: Jul. 24, 2014. doi: 10.1111/j.1399-3054.2004.00402.x.

DOURADO-NETO, D. et al. Software to model soil water retention curves (SWRC, version 2.00). Scientia Agricola, v.57, n.1, p.191-192, 2000. Available from: <http://www.scielo. $\mathrm{br} / \mathrm{scielo.php}$ ?pid=S0103-90162000000100031\&script $=\mathrm{sci}$ arttext>. Accessed: Jul. 24, 2014. doi: 10.1590/S010390162000000100031.

DUFOUR, L; GUÉRIN, V. Growth, developmental features and flower production of Anthurium andreanum Lind. in tropical conditions. Scientia Horticulturae, v.8, n.1, p.25-35, 2003 Available from: <http://www.sciencedirect.com/science/article/ pii/S0304423802001966>. Accessed: Jul. 24, 2014. doi: 10.1016/ S0304-4238(02)00196-6.

EMPRESA BRASILEIRA DE PESQUISA AGROPECUÁRIA EMBRAPA. Manual de métodos de análises de solo. 2 ed. Rio de Janeiro, 1997. 212p. Available from: <http://www.agencia. cnptia.embrapa.br/Repositorio/Manual+de+Metodos_000fzvhotq k02wx5ok0q43a0ram31wtr.pdf $>$. Accessed: Jan. 3, 2012.

FREITAS JÚNIOR, E.; SILVA, E.M. Uso da centrífuga para determinação da curva de retenção de água do solo, em uma única operação. Pesquisa Agropecuária Brasileira, v.19, n.11, p.14231428, 1984. Available from: <http://seer.sct.embrapa.br/index. php/pab/article/view/16199/10375>. Accessed: Jul. 24, 2014.

GANTAIT, S.; MANDAL, N. Tissue culture of Anthurium andreanum: a significant review and future prospective International Journal of Botany, v.6, n.3, p.207-219, 2010 Available from: $<$ http://scialert.net/abstract/?doi=ijb.2010.207.219>. Accessed: Mar. 27, 2015. doi: 10.3923/ijb.2010.207.219.

HIGAKI, T. et al. Anthurium culture in Hawaii. Honolulu: University of Hawaii, 1995. 23p. (HITAHR Research Series, 152).

JAFARI, M. et al. Mulching impact on plant growth and production of rainfed fig orchards under drought conditions. Journal of Food, Agriculture \& Environment, v.10, n.1, p.428-433, 2012. Available from: <http://www.world-food.net/download/ journals/2012-issue_1/a45.pdf $>$. Accessed: Mar. 27, 2015.

JUN, F. et al. Mulching effects on water storage in soil and its depletion by alfalfa inthe Loess Plateau of northwestern China. Agricultural Water Management, v.138, n.31, p.10-16, 2014 Available from: $<$ http://www.sciencedirect.com/science/article/pii/ S037837741400064X>. Accessed: Mar. 27, 2015.

KUOTSU, K. et al. Land forming and tillage effects on soil properties and productivity of rainfed groundnut (Arachis hypogaea L.)-rapeseed (Brassica campestris L.) cropping system in northeastern India. Soil \& Tillage Research, v.142, p.15-24, 2014. Available from: <http://www.sciencedirect.com/science/ article/pii/S016719871400083X>. Accessed: Mar. 28, 2015.

LASKOWSKA, H. et al. The effect of bulb planting time and type of mulch on the yield of Allium aflatunense B. Fedtsch. Acta Agrobotanica, v.65, n.4, p.117-122, 2012. Available from:
$<$ https://pbsociety.org.pl/journals/index.php/aa/article/view/1352>. Accessed: Mar. 31, 2015. doi: 10.5586/aa.2012.028.

MODENESE-GORLA DA SILVA, S.H. et al. Estimativa da área foliar de antúrio com funções de regressão. Ciência Rural, v.38, n.1, p.243-246, 2008. Available from: <http://www.scielo.br/ scielo.php?script $=$ sci arttext\&pid $=$ S0103-84782008000100040>. Accessed: Jul. 24, 2014. doi: 10.1590/S0103-84782008000100040.

MULUMBA, L.N.; LAL, R. Mulching effects on selected soil physical properties. Soil \& Tillage Research, v.98, n.1, p.106111, 2008. Available from: $<$ http://www.sciencedirect.com/science/ article/pii/S0167198707001985>. Accessed: Mar. 27, 2015.

MUPANGWA, W. et al. Cumulative effects of reduced tillage and mulching on soil properties under semi-arid conditions. Journal of Arid Environments, v.91, p.45-52, 2013. Available from: <http:// www.sciencedirect.com/science/article/pii/S014019631200314X>. Accessed: Mar. 27, 2013.

NOMURA, E.S. et al. Crescimento e produção de anthurium submetido a diferentes intensidades de desfolha. Ciência Rural, v.41, n.4, p.602-607, 2011. Available from: <http://www.scielo.br/ scielo.php?pid=S0103-84782011000400009\&script $=$ sci_arttext $>$. Accessed: Jul. 24, 2014. doi: 10.1590/S0103-84782011005000043.

RAMAKRISHNA, A. et al. Effect of mulch on soil temperature, moisture, weed infestation and yield of groundnut in northern Vietnam. Field Crops Research, v.95, n.2-3, p.115-125, 2006. Available from: <http://www.sciencedirect.com/science/article/ pii/S0378429005000560>. Accessed: Mar. 28, 2015. doi: 10.1016/j.fcr.2005.01.030.

SINKEVIČIENĖ, A. et al. The influence of organic mulches on soil properties and crop yield. Agronomy Research, v.7, sp. issue I, p.485-491, 2009. Available from: http://agronomy.emu.ee/ vol07Spec1/p7sI53.pdf. Accessed: Jul. 24, 2014. doi: 10.1111/ j.1475-2743.2000.tb00196.x.

SOIL SURVEY STAFF. Keys to soil taxonomy. 11.ed. Washington: USDA-Natural Resources Conservation Service, 2010. 346p.

TOMBOLATO, A.F.C. et al. O cultivo de antúrio: produção comercial. Campinas: Instituto Agronômico, 2002. 47p. (Série Tecnológica APTA, Boletim Técnico IAC, n.194).

VAN GENUCHTEN, M.T. A closed-form equation for predicting the hydraulic conductivity of unsaturated soils. Soil Science Society of America Journal, v.44, p.892-898, 1980.

VENKAT, S.K. et al. The genetic linkage maps of Anthurium species based on RAPD, ISSR and SRAP markers. Scientia Horticulturae, v.178, p.132-137, 2014. Available from: <http:// www.sciencedirect.com/science/article/pii/S0304423814004609>. Accessed: Mar. 27, 2015.

YOUNIS, A. et al. Effect of different types of mulching on growth and flowering of Freesia alba cv. 'Aurora'. Pakistan Journal of Agricultural Sciences, v.49, n.4, p.429-433, 2012. Available from: $<$ http://pakjas.com.pk/papers\%5C2083.pdf>. Accessed: Mar. 28, 2015.

ZHANG, S. et al. Effects of mulching and catch cropping on soil temperature, soil moisture and wheat yield on the Loess Plateau of China. Soil \& Tillage Research, v.102, n.1, p.78-86, 2009. Available from: $<$ http://www.sciencedirect.com/science/article/pii/ S0167198708001244>. Accessed: Mar. 28, 2015. doi:10.1016/j. still.2008.07.019. 